\title{
POSSIBILITY OF IN-HOSPITAL INFECTION BY Cryptococcus neoformans IN PATIENTS WITH AIDS
}

\author{
Maria Elena RUSTAN, Héctor R. RUBINSTEIN, Carmela SICILIANO \& Diana T. MASIH.
}

\section{SUMMARY}

The objective of the present work was to carry out a survey of soil samples taken from different areas of a hospital of infectious disease located in the city of Cordoba, where three AIDS patients were hospitalized during different periods in the same ward. The three of them returned with meningeal cryptococcosis between three or five months after having been discharged. Cryptococcus neoformans was isolated in $8 / 10$ samples collected outside the hospital, near the pigeon house. The samples collected from the AIDS patients ward and its surroundings were negative. These findings suggest that the patients may have been infected by the fungus during their first stay in hospital

KEY WORDS: Cryptococcus neoformans; AIDS; Meningitis.

\section{INTRODUCTION}

Cryptococcus neoformans is the etiologic agent that causes a systemic mycosis of worldwide distribution. It has been isolated from soil samples particularly from soil where pigeon excrements were found ${ }^{(1,3,6,7)}$. A continuous relationship between this microorganism and old nests and pigeon excrements in domes, comices, buildings, etc. has been found because their excrements, which are rich in nitrogen and have a high content of alkaline $\mathrm{pH}$ salts, are responsible for the long survival of this fungus ${ }^{(4)}$.

Some samples were taken from soils contaminated with pigeon excrements in the cities of Villa Dolores and Alta Gracia in the Province of Cordoba, Argentina in $1989^{(10)}$. Man is infected with $\mathbf{C}$. neoformans by inhalation producing a primary benign pulmonary infection. If this primary infection is not overcome, it can either remain in the lung or scatter and produce a systemic infection which is generally lethal. The main region of scattering is the central nervous system, particularly the meninges ${ }^{(11)}$.

Infections caused by $\mathrm{C}$. neoformans produce significant morbidity and high mortality, particularly among immunocompromised patients. Cryptococcal meningitis is an important cause of disease of the central nervous system and of death in patients with $\operatorname{AIDS}^{(13,14)}$.

Three patients with AIDS, who shared the same room during different periods of time, returned to hospital with cryptococcic meningitis a few months after they had been allowed to leave as a result of the improvement in their health. Therefore, it was decided to search for this fungus in the room where these patients had stayed, in the inner courtyards of the hospital and in its pigeon house.

\section{MATERIALS AND METHODS}

Hospital Rawson is in charge of patients suffering from infectious diseases and is situated in the south-east of the city of Cordoba, capital of the Province of Cordoba; it is located between the East entrance to the city and the railways. It is surrounded by green areas, a zoo, temporary circus grounds (Fig. 1). It is $440 \mathrm{~m}$ above the sea level and the climate is temperate with remarkable differences between summer and winter. It rains around $600-800 \mathrm{~mm}$ yearly.

Cátedra de Parasitologia y Micologia.:Dpto. Bioquímica Clínica. Facultad de Ciencias Químicas. Universidad Nacional de Córdoba. Córdoba. Argentina.

Address for correspondence: Dra. Diana T. Masih. Parasitologia y Micologia. Dpto. Bioquímica Clínica. Universidad Nacional de Cordoba. Suc. 16 - CC 61 (5016) Córdoba. Argentina. 


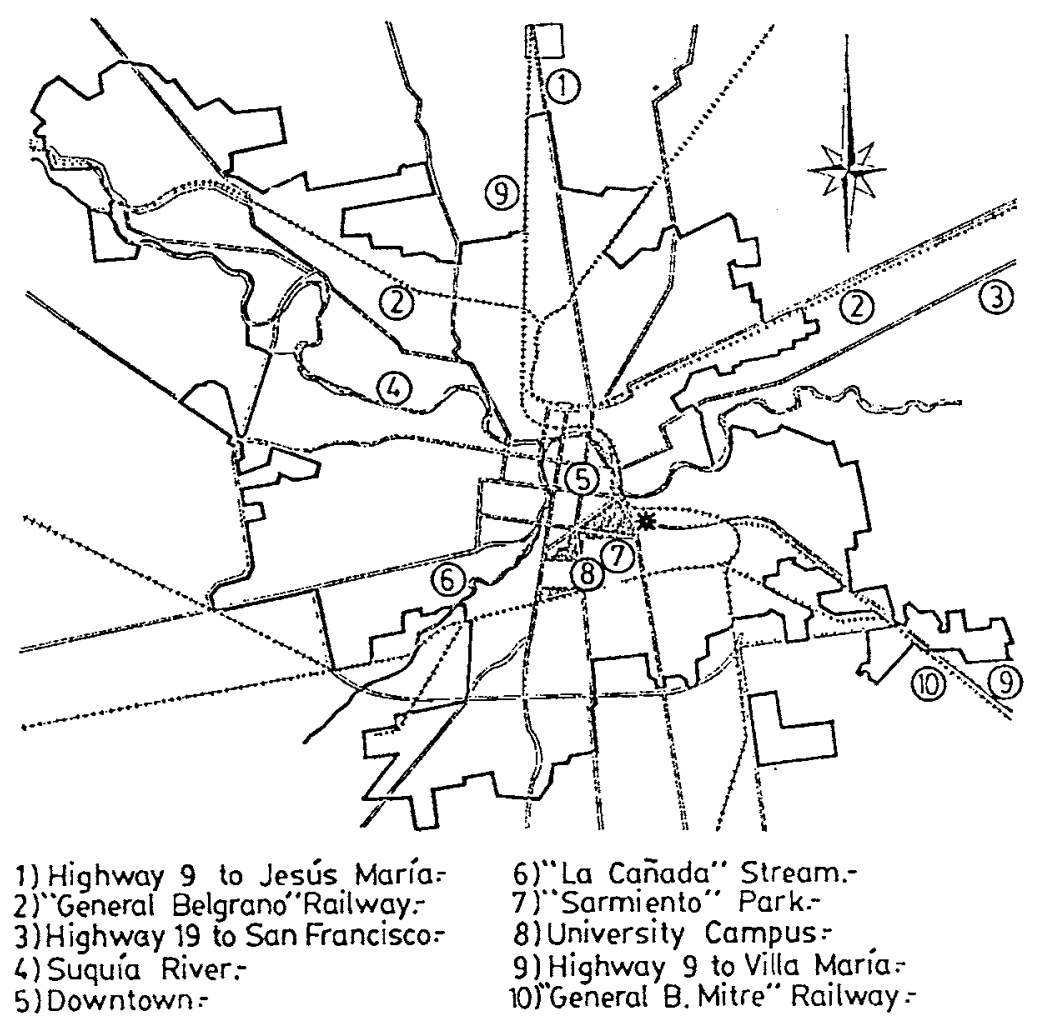

Figure 1: Location of the hospital $\left({ }^{*}\right)$. It is situated in the Southeast of the city of Cordoba. It is located between the East entrance to the city and the railways. It is surrounded by green areas, a zoo and temporary circus grounds.

\section{Isolation of samples}

The samples were taken from five different places of the hospital as shown in Fig. 2. Points 1, 2,4 and 5 show the samples taken from soil contaminated with pigeon excrements; in point 3 , which corresponds to the room of patients with AIDS, the samples were taken from the surroundings and the inside without contamination of pigeon excrements but containing other detritus such as vegetal debris. The collection was made with sterile wooden spatulas and kept in sterile glass containers at room temperature until used.

All the samples were processed by duplicate following SHIELDS \& AJELLO'S method ${ }^{(12)}$ with modifications as proposed by CIVILA \& CONTI DIAZ $^{(3)}$. Briefly, between 13 and $15 \mathrm{~g}$ of sample were solubilized in $50 \mathrm{ml}$ of sterile physiological solution and allowed to rest for $15 \mathrm{~min}$. Then, $8 \mathrm{ml}$ of the different layers of the supernatant were taken and $4.5 \mathrm{mg}$ of penicillin and $10 \mathrm{mg}$ of streptomycin were added. The material was spread on Petri dish plaques by scattering in the middle of the agar sunflower seed extract (ASSE), another was inoculated to Rockefeller mice and another was spread in tubes on Sabouraud glucose.

\section{Agar sunflower seed extract (ASSE)}

Sunflower seeds $(90 \mathrm{~g})$ were ground in $100 \mathrm{ml}$ of distilled water. The macerate was boiled for 30 min in $900 \mathrm{ml}$ of distilled water, then was filtered through gauze and adjusted to the volume of the aqueous extract at $1000 \mathrm{ml}$, Bacto-agar (Difco) was added and dissolved by heating the matrass in boiling water. Sterilization was made at a pressure of $1 \mathrm{~atm}$ and at a final $5.5 \mathrm{pH}(8)$. The plaques thus spread were incubated at $37^{\circ} \mathrm{C}$ and checked daily for 10 days.

Strains of Candida albicans, C. tropicalis and Cryptococcus neoformans were used as control of the culture media.

Only C. neoformans developed colonies pigmented with a dark chestnut brown colour. From the studied samples spread on the ASSE medium, only those that developed creamy pigmented colonies were purified for characterization.

Tests of urease, development at $37^{\circ} \mathrm{C}$, carbohydrates and $\mathrm{NO}_{3} \mathrm{~K}$ assimilation tests and 21 day Rockefeller mouse intracranial inoculation were carried out. 

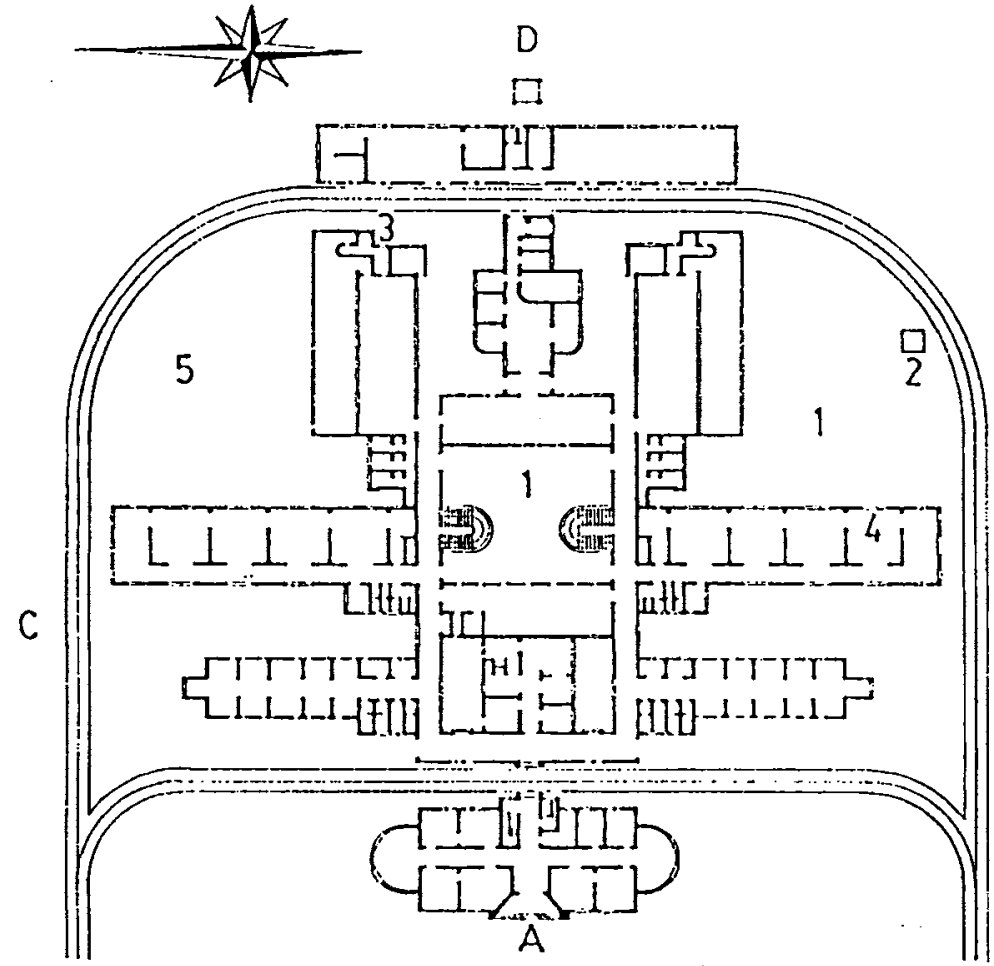

Figure 2: Plan of the hospital. Isolation of samples taken from five different places of the hospital. Points 1, 2, 4 and 5 show the samples taken from soil contaminated with pigeon excrements. Point 3 corresponds to the room of patients with AIDS.
Zone 1: Patio

Zone 2: Pigeon breed place

Zone 3: AIDS patients room

Zone 4: first floor and open roof

Zone 5: Parking area
A: Entrance to hospital
B: Highway 9
C: Street
D: Urban district

Four to eight week old Rockefeller mice were intraperitoneally (ip) inoculated with $0.5 \mathrm{ml}$ of the suspension from the soil samples. On the 30 day post inoculation the animals were killed removing their brain, lung, kidney, spleen and adrenal glands for their homogeneization. This material was examined directly with Indian ink, ASSE and Sabouraud cultures.

\section{Clinical Case}

Patient M.O.: male, 29 years old, from Colonia Caroya in the Province of Cordoba; occupation: bank clerk. Hemophilic, showing a three month febrile history on the first consultation with loss of weight and oropharynx esophagic candidiasis. The HIV was positive. The patient recovered after a treatment of 15 days but returned five months later presenting intense headache, rigidity in the nape of the neck and loss of consciousness for a few seconds, with fever and ocular deviation. Cryptococcus neoformans was isolated from blood, spinal fluid and urine.

Patient E. M.: male, 38 years old, homosexual, from Pilar in the Province of Cordoba; occupation: mechanic. He presented disseminated Kaposi Sar- coma, stage IV and HIV positive. After a four month period of consultation including several hospitalizations, the patient was admitted to the hospital with fever, headache and temperament changes. Cryptococcus neoformans was isolated from spinal fluid and blood.

Patient J.C.: male, 25 years old, from Cordoba city, no permanent employment. Hemophilic. He was admitted to the hospital with neumopathy and oral and pharynx esophagic candidiasis. The HIV was positive. His recovery was satisfactory but he was again hospitalized after three months with the diagnosis of headache and fever. Cryptococcus neoformans was isolated from spinal fluid.

It should be remarked that these three patients were hospitalized in the same room during different periods of time.

\section{RESULTS}

To determine whether C.neoformans was present in the environment of the hospital, samples of dust and soil were taken from the rooms where these three patients had been hospitalized, and soil from the surroundings with and without pigeon ex- 
RUSTAN, M.E.; RUBINSTEIN, H.R; SICILIANO, C. \& MASIH, D.T. - Possibility of in-hospital infection by Cryptococcus neoformans in patients with AIDS. Rev. Inst. Med. trop. S. Paulo, 34 (5): 383-387, 1992.

crements. From the five places chosen in the hospital (Fig. 2), C. neoformans was isolated in $8 / 10$ samples taken from zone $2\left(12 \mathrm{~m}^{2}\right)$ which corresponds to the pigeon house.

The results from the samples obtained by inoculation of mice and sowing on the ASSE and Sabouraud are shown in Table 1.

Table 1

Isolation of Cryptococcus neoformans from the soil

\begin{tabular}{ccc}
\hline Zones & $\begin{array}{c}\text { Agar sunflower } \\
\text { seed extract* }\end{array}$ & $\begin{array}{c}\text { Inoculation } \\
\text { of mouse** }\end{array}$ \\
\hline 1 & $0 / 10$ & $0 / 10$ \\
2 & $7 / 10$ & $8 / 10$ \\
3 & $0 / 10$ & $0 / 10$ \\
4 & $0 / 10$ & $0 / 10$ \\
5 & $0 / 10$ & $0 / 10$ \\
\hline
\end{tabular}

* The plaques were incubated at $37^{\circ} \mathrm{C}$ and checked daily for 10 days.

** Mice were ip inoculated with $0.5 \mathrm{ml}$ of the suspension from the soil samples.

All dark chestnut brown cultures developed in ASSE, urease positive, assimilated inositol and xilose but not lactose or $\mathrm{NO}_{3} \mathrm{~K}$. They were intracranially inoculated to 21 day old mice producing macroscopic lesions in the skull with several morphological $C$. neoformans characteristic sheath yeasts between 7 and 15 days after inoculation. The $C$. neoformans colonies isolated on ASSE were also isolated on Sabouraud. The former resulted in a better and quicker recovery for their identification than Sabouraud.

When the sunflower seed was replaced by alpist in the ASSE, the C. neoformans colonies developed very slowly without pigmenting.

\section{DISCUSSION}

Cryptococcic meningitis is one of the most important neurological manifestations in AIDS patients. It can occur during the infection by HIV, or as an opportunist infectious disease or as a subsequent after-effect in AIDS patients on the basis of malignant infections related to AIDS $^{(5)}$. From the 34 patients treated in Bellevue Manhattan UAMC, cryptococcosis was the first manifestation observed among 16 patients $^{(15)}$. From the 27 AIDS patients with criptococcosis reported by KOVACS et al.(9), criptococcosis was the first disease diagnosed in seven patients.
The three patients with AIDS here reported remained in the hospital for their HIV treatment. They achieved a general improvement so they were released but the three of them systematically returned showing neurological symptons and spinal fluid $\mathbf{C}$. neoformans was isolated. Thus, it was thought that the patients contaminated when they got in contact with the fungus in the same environment. Therefore, this fungus was searched for within the hospital environment.

In the literature reviewed by BIANCHI et al. ${ }^{(2)}$, C. neoformans is scarcely mentioned as the agent of hospital infection although it is pointed out that a risky infectious source is constituted by persons with HIV positive serum and with AIDS.

On account of this probable hospital infections by $\mathrm{C}$. neoformans and other fungi, BIANCHI et al. ${ }^{(2)}$ suggest demolition of buildings, checking on workers, decontamination of pigeon excrements with $3 \%$ formaldehyde and isolation of patients with infections by HIV.

Although the data here reported do not confirm that the $\mathbf{C}$. neoformans infection occurred in the hospital, this possibility should not be complety disregarded.

\section{RESUMEN}

Posibilidad de infección intra - hospitalaria por Cryptococcus neoformans en pacientes con SIDA

El objetivo del presente trabajo fue realizar un relevamiento de muestras de suelo en distintas áreas de un hospital de enfermedades infecciosas de la Ciudad de Córdoba, donde estuvieron internados tres pacientes con sindrome de inmuno deficiencia adquirida (SIDA). Ocuparon en distintos períodos de internación la misma sala. Los tres reingresaron al nosocomio entre los tres y cinco meses siguientes de haber sido dados de alta, con meningitis criptococcica. Cryptococcus neoformans se pudo aislar en 8/ 10 muestras recogidas en la zona exterior del hospital próxima al palomar. Las muestras tomadas en el interior de la sala destinada a la internación de pacientes con SIDA y de sus alrededores resultaron negativas. Estos hallazgos sugieren que probablemente los pacientes se infectaron con el hongo durante su primeira internación. 
RUSTAN, M.E.; RUBINSTEN, H.R; SICILIANO, C. \& MASIH, D.T. - Possibility of in-hospital infection by Cryptococcus neoformans in patients with AIDS. Rev. Inst. Med. trop. S. Paulo, 34 (5): 383-387, 1992.

\section{REFERENCES}

1. BAVA, A. J.\& NEGRONI, R.- Estudio epidemiologico sobre criptococosis en San Pedro (Prov. de Bs. As.). Rev. argent. Micol.,9 (3): 12-16, 1986.

2. BIANCHI, M.; BAVA, A. J. \& NEGRONI, R.- Estudio de fuentes intrahospitalarias de infección por Cryptococcus neoformans. Infectol. Microbiol. clin., 1:107$111,1989$.

3. CIVILA, E. \& CONTI DIAZ, I.A.- Aislamiento de Cryptococcus neoformans de excretas secas de palomas en la ciudad de Montevideo. Rev. urug. Pat. clin. Microbiol., 3:41-48, 1976.

4. CONANT, N.F.; SMITH, D.T.; BAKER, R.D. \& CALLAWAY, L.L.-Manual of clinical mycology. Philadelphia, W.B. Saunders, 1971. Chapter 7, p. 149-168.

5. DISMUKES, W.- Cryptococcal meningitis in patients with AIDS. J. infect. Dis., 157: 624-628, 1988.

6. EMMONS, C.- Isolation of Cryptococcus neoformans from soil. J. Bact., 62: 685-689, 1951.

7. EMMONS, C.- Saprophytic sources of Cryptococcus neoformans associated with the pigeon. Amer. J. Hyg., 62: $277-282,1955$.

8. KONEMAN, E.W. \& ROBERTS, G.D.- Micologia practica de laboratorio. Buenos Aires, Editorial Medica Panamericana, 1987. Chapter 7,p. 175-195.

9. KOVACS, S.A.; KOVACS, A.A.; POLIS, M.; WRIGTII, W.C.; GILL, V.J.; TUAZAN, C.U.; GELMANN, E.P.;
LANELT, C.; LONGFIELD, R.; OVERTURF, G.; MACHER, A.M.; FAUCI, A.S.; PARRILLO, J.E.; BENNETT, J.E. \& MASUR, H.-Cryptococcosis in the acquired immunodeficiency syndrome. Ann. intern. Med., 103: 533-538, 1985.

10. RUBINSTEIN, H.; MARTICORENA, B.; MASIH, D.; BORLETTO, N.; VEGA, R.; VARENGO, H. \& NEGRONI, R. - Isolation of human fungi from soil and identification of two endemic areas of Cryptococcus neoformans and Coccidioides immitis. Rev. Inst. Med. trop. S. Paulo, 31 : 1-6, 1989.

11. RUBINSTEIN, P. \& NEGRONI, R. - Micosis broncopulmonares del adulto y del niño. Buenos Aires, Editorial Beta, 1981. Chapter 8, p. 325-337.

12. SHIELDS, A. B. \& AJELLO, L.- Medium for selective isolation of Cryptococcus neoformans. Science, 151: 208-209, 1966.

13. SHIMIZU, R.Y.; HOWARD, D.H. \& CHANCY, M.N.The variety of Cryptococcus neoformans in patients with AIDS. J.infect.Dis., 154: 1042 - 1043, 1986.

14. SUGAR, A.M.; STERN, J.J. \& DUPONT, B. - Overview: treatment of Cryptococcal meningitis. Rev. infect. Dis., 12: 338-348, 1990.

15. ZUGER, A.; LOUIE, E.; HOLZMAN, R.; SIMBERKOFF, M.S. \& RAHAL, J. - Cryptococcal disease in patients with the acquired immunodeficiency syndrome. Diagnostic features and outcome of treatment. Ann. intern. Med., 104: 234-240, 1986.

Recebido para publicação em 23/9/1991 Aceito para publicaçāo em 14///1992 